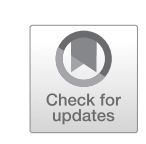

\title{
Imperial Aetiologies: Violence, Sleeping Sickness, and the Colonial Encounter
}

There are some places in the world where a curse seems to brood in the atmosphere. Msala was one of these. Perhaps these places are accursed by the deeds that have been done there. ${ }^{1}$

This passage from Henry Seton Merriman's With Edged Tools (1894) opens a pivotal chapter in the novel. A few pages later antagonist Victor Durnovo will die, melodramatically, of sleeping sickness - the drama heightened by his recently mutilated face. As his companions shake his lifeless body in an attempt to rouse him from a sleep 'that knows no earthly waking', we are confronted with a memorably violent image. Durnovo's 'mutilated inhuman head' rolls on his shoulders, round lidless balls staring. The sleeping sickness is both retribution for his crime of keeping slaves under the guise of fair employment and a Divine concession to 'soften' the punishment dealt out by those slaves when they finally revolt. Durnovo's contraction of sleeping sickness is foreshadowed by his own suggestion early in the tale that should he go back on his words, God should strike him dead. Later, as he flees across the country spreading the illness in his wake, the sleeping sickness becomes a 'grim legacy to his torturers' (382).

\footnotetext{
${ }^{1}$ Henry Seton Merriman, With Edged Tools (1894; London: Smith, Elder, \& Co., 1909) p. 373.

(C) The Author(s) 2022

E. Taylor-Pirie, Empire Under the Microscope, Palgrave Studies in

Literature, Science and Medicine, https://doi.org/10.1007/978-3-030-84717-3_5
} 
Enmeshed within a lexis of curses, bad deeds, and retribution, sleeping sickness is difficult to separate from the violence that surrounds it. Indeed, violence and disease become the dominant lenses through which readers of With Edged Tools experience the colonial world. Merriman introduces his adventurers to outbreaks of malaria, smallpox, and sleeping sickness on their journey, and employs a metaphor of 'irritability' that stands in for both Africa's tropical diseases and its imagined moral shortcomings. In a narrative entanglement between climatism, germ theory, and racialised understandings of emotion, Merriman casts tropical disease and violent behaviour as issuing from the landscape at large:

[T] he irritability of Africa [...] no one knows what it is, but it is there, and sometimes it is responsible for murder $[\ldots]$ inhaled into the white man's lungs with the air of equatorial Africa $[\ldots]$ there are moral microbes in the atmosphere. (51-52)

Here the vocabularies of germ theory and of miasmatism provide a rhetorical multivalence that enables Merriman to map the medical and moral dangers of inhabiting African space in close proximity.

Alan Bewell has argued that during the eighteenth and nineteenth centuries, 'medicine shaped how space was perceived', medical cartography offering writers 'a vocabulary $[\ldots]$ for conceiving colonial spaces as spaces that were sick and needed to be cured'. ${ }^{2}$ This stems, as Bewell is careful to note, from an epidemiological reality-from what he refers to as the 'world-making and world-shattering traffic in pathogens' that colonial expansion entailed (9). The characterisation of parts of the globe as morbidly dangerous to Europeans was therefore much more than 'a metaphoric projection of European insecurities or biases' (10). The inclusion of parasitic diseases like malaria and sleeping sickness in imperial fiction reflects a very real part of the colonial encounter. Nevertheless, the nature of these inclusions also reflects ideological assumptions about the epidemiological, political, and social relationships between Britain and the rest of the globe. In this chapter, I explore how writers' engagement with the relationship between tropical disease and space created rhetorical opportunities for shaping not only the geographical and etiological but also the sociocultural topographies of empire.

\footnotetext{
${ }^{2}$ Alan Bewell, Romanticism and Colonial Disease (Baltimore: Johns Hopkins University Press, 1992) p. 18.
} 
Merriman's irritability metaphor in With Edged Tools is one that pathologises the colonial encounter and collapses the perceived medical and moral problems of West Africa into one. It joins a string of verbal depictions that painted Africa as part of an archetypal tropics that was productive of violence, immorality, and illness in equal measure. Such depictions are recognisable in a range of texts from Patrick Manson's 1898 textbook Tropical Diseases, which claimed 'backwards social and insanitary conditions' are 'more or less an indirect outcome of tropical climate', to British explorer Edward Glave's travel narrative in which he describes the colonial encounter as a struggle against 'jabbering natives', 'fierce savages', 'mosquitoes', and 'deadly fever'. ${ }^{3}$ As scholars such as Warwick Anderson, David Arnold, Anna Crozier, Charlotte Rogers, Nancy Leys Stepan, and Mary Louise Pratt have argued, the colonies - especially those possessions characterised as 'tropical' - occupied a prime position in the imperial imagination as spaces of social and sanitary inferiority onto which Europeans could project their 'fears, fantasies, and assumptions about non-Western cultures'. 'Tropicality' became an ideologue that signified not just geography, but 'radical otherness to the temperate world' ${ }^{5}$

This 'otherness' was increasingly medicalised as the nineteenth century drew to a close, bringing the administration and management of the colonies within the purview and authority of tropical medicine. Writing about American colonialism, Anderson lays out the 'civic vision' (though we might also say civic 'mission') of medicine and science in colonial settings. $\mathrm{He}$ argues that since defeating Spanish powers in the Philippines 'American colonial authorities had eagerly taken up the burden of cleansing their newly acquired part of the Orient, attempting to purify not only its public spaces, water, and food, but also the bodies and conduct of its inhabitants'. More generally, tropical medicine was mobilised to 'diagnose' undesirable ideologies and behaviours; Crozier has argued, for example,

\footnotetext{
${ }^{3}$ Patrick Manson, Tropical Diseases: A Manual of the Diseases of Warm Climates (London: Cassell and Company, 1898) p. xvi; E. J. Glave, Six Years of Adventure in Congo-Land (London: Sampson Low, Marston and Company, 1893) p. 39.

${ }^{4}$ Charlotte Rogers, Jungle Fever: Exploring Madness and Medicine in Twentieth-Century Tropical Narratives (Nashville: Vanderbilt University Press, 2012) p. 8.

${ }^{5}$ Nancy Leys Stepan, Picturing Tropical Nature (London: Reaktion Books, 2012) p. 17.

${ }^{6}$ Warwick Anderson, Colonial Pathologies: American Tropical Medicine, Race, and Hygiene in the Philippines (Durham: Duke University Press, 2006) p. 1.
} 
that the sociocultural habits of native Africans were routinely associated with disease in European medical writing. ${ }^{7}$

In his 2017 book Malarial Subjects, Rohan Deb Roy ascribes a complex clinical, ideological, and instrumental multiplicity to depictions of malaria-an illness that dominated nineteenth-century tropical narratives:

Malaria became entangled with the diagnoses of an exhaustive range of everyday and spectacular illnesses; the management of individual and collective bodies; the prejudices of smell, colour, and class; efforts to make sense of lands, landscapes and objects; and debates about agricultural improvement, land revenue, as well as urban and sanitary governance. ${ }^{8}$

Anne H. Kelly and Uli Beisel likewise write of multiple 'malarias', recognising the divergent biological, behavioural, and sociopolitical understandings and experiences of the disease in the past. 'By referencing "malarias" at times in the plural', they assert, 'we seek to unpack the multiple concepts of disease, their attendant differences in intervention and the various biomedical realities that are often elided by the single word "malaria"'. 'Meanwhile, Jessica Howell has argued that malaria wields narrative power in nineteenth-century fiction as 'an iconic disease of empire' owing in part to its rhetorical flexibility. ${ }^{10}$ Here I broaden the focus to include another iconic disease of empire, sleeping sickness, and explore how one sociopolitical understanding of this disease-as a form of tropical violence-emerged at the intersections of literature and medicine.

At the turn of the century, entanglements between anthropological, literary, and medical observations were difficult to tease apart because they operated within the echo chamber of the medico-literary imagination. For example, Glave encoded an association between Africa, violence, and disease in his travel narrative when describing a combat between 'two young warriors'. ${ }^{11}$ The fighters 'presented a ghastly appearance', their bodies

${ }^{7}$ Anna Crozier, 'Sensationalising Africa: British Medical Impressions of Sub-Saharan Africa, 1890-1939' The Journal of Imperial and Commonwealth History 35.3 (September 2007) 393-415.

${ }^{8}$ Rohan Deb Roy, Malarial Subjects: Empire, Medicine, and Nonhumans in British India, 1820-1909 (Cambridge: Cambridge University Press, 2017) p. 5.

${ }^{9}$ Anne H. Kelly and Uli Beisel, 'Neglected Malarias: the Frontlines and Back Alleys of Global Health’ BioSocieties, 6.1 (2011) 71-87 (footnote 4, p. 73).

${ }^{10}$ Jessica Howell, Malaria and Victorian Fictions of Empire (Cambridge: Cambridge University Press, 2019) p. 1.

${ }^{11}$ Glave, Six Years of Adventure in Congo-Land, p. 140. 
'flooded with crimson' and the ground beneath their feet 'saturated with their blood'. The fight, he informed his readers, was started over a phrase: owa na ntolo, which means 'may you die of sleeping sickness'. So dreaded is this disease that

it has been embodied into one of [Africa's] bitterest curses, and no man expresses his hatred of another in this insulting form [...] without first grasping his knife in readiness, as this utterance is a direct challenge to fight, and no one but a coward will fail to accept it. (141)

The story was repeated in a clinical account of sleeping sickness written by Patrick Manson for the multi-volume textbook A System of Medicine in 1897 and retained in the entry written by G. C. Low in the 1907 edition: 'The bitterest malediction one negro can pronounce on another is owa na ntolo - may you die of sleeping sickness'. ${ }^{12}$ The sentiment was also repeated in two ethnographic texts on the Congo tribes published by Herbert Ward in 1891 and 1910 - 'the direst curse a native can call down on an adversary is to express a wish that he may be "waka ntolo" (struck with sleep)'; "the direst and most effective curse a Babangi native can pronounce is "waka ntolo" (may you die of sleep)'. ${ }^{13}$ As we have seen, the disease was similarly characterised as a violent curse in imperial romance fiction-perhaps most memorably by Merriman in the scene with which I openedand, coming full circle, Merriman's novelistic encounter with sleeping sickness was itself widely cited as a cultural referent in medical articles as well as international journalism regarding outbreaks of the disease in the British protectorate of Uganda. The use of such a sensational literary moment to facilitate the public understanding of problems facing

\footnotetext{
${ }^{12}$ Patrick Manson, 'Negro Lethargy, or Sleeping Sickness' in A System of Medicine by Many Writers vol II. ed. by Thomas Clifford Allbutt (London: Macmillan and Co., 1897) p. 480; G. C. Low, 'Sleeping Sickness' A System of Medicine, by Many Writers Vol II. Part II. ed. by Thomas Clifford Allbutt and Humphrey Davy Rolleston (London: Macmillan and Co., $1907)$ p. 210 . The entry by Low was specifically referenced in John Masefield's sleeping sickness novel Multitude and Solitude (1909).

${ }^{13}$ Herbert Ward was an officer in Sanford Exploring Company alongside Joseph Conrad and worked in the Upper and Lower Congo region before joining H. M. Stanley's Emin Pasha Relief expedition in 1887. He went on to publish Five Years with the Congo Cannibals (1891), My Life with Stanley's Rear Guard (1891), and A Voice from the Congo (1910). Ward, Five Years with the Congo Cannibals (London: Chatto \& Windus, 1891) p. 51; Ward, A Voice from the Congo; Comprising Stories, Anecdotes, and Descriptive Notes (London: William Heinemann, 1910) p. 254.
} 
imperial administration reveals how conceptions of empire were augmented by a multi-vocal medicalisation of the colonial encounter. Moreover, depictions of sleeping sickness as a racially specific and violent curse perpetuated ideas about the distinctness of African experiences of illness, culminating in diagnoses like 'negro lethargy' and 'white-man lethargy' as I examine towards the end of the chapter.

\section{STRANGER THAN Fiction}

When The Bookman reviewed John Masefield's imperial romance novel, Multitude and Solitude (1909), the anonymous reviewer dubbed it 'an all-absorbing study of that most interesting tropical disease, Sleeping Sickness'. ${ }^{14}$ The novel, which follows failing-playwright-turned-amateurexplorer, Roger, as he travels to Africa to find a cure for sleeping sickness, is full of technical language and-as both this and other reviewers notedhas a 'striking image of glossina palpalis' (a tsetse fly) on its cover. Thus, it shared aesthetic convention with textbooks of tropical medicine. Such paratextual elements contributed to the ambiguous epistemic status of the novel, which included detailed information about the aetiology and prophylaxis of sleeping sickness and dedicated considerable space to descriptions of microbes: '[trypanosomes are] like little wriggly flattened membranes. Some of them have tails. They multiply by longitudinal division', as well as to the aetiology and prophylaxis of tropical illness. ${ }^{15}$ Masefield's more-than-literary interest in sleeping sickness is evident in his staging of contemporaneous medical debates through stilted character dialogue:

"I believe that the cure (if there is one) will be got by injecting the patient with dead trypanosomes, or very very weak ones. I'm going to make a special artificial culture of trypanosomes in culture tubes. I shall then weaken the germs with atoxyl."

"And I," rejoined Roger, "believe that your methods will be useless. I believe that the cure (if there is one) will be obtained from naturally or artificially immunised animals". (231)

14 'Multitude and Solitude by John Masefield' The Bookman 37.217 (October 1909) p. 58.

${ }^{15}$ Masefield, Multitude and Solitude, p. 142. 
The novel also nods to the racial politics that underpinned medical discussions of the disease when Lionel drily observes 'sleeping sickness must be getting worse. It attacks Europeans sometimes. Mackenzie said that in his time it never did' (120).

Such detours are probably what led Miss G. C. Westbrook to scathingly characterise the second half of the book as 'a rather monstrous dissertation concerning sleeping sickness'. ${ }^{16}$ With a similar tone a reviewer for The Sketch predicted that 'the seriousness of Multitude and Solitude' would 'prevent it from attaining any high degree of popularity' especially 'when it is written with the accuracy that Mr John Masefield exhibits'. Nevertheless, they asserted that the novel is a 'better sermon than you are likely to hear in a hundred churches' ${ }^{17}$ This was a novel with a message, and many reviewers praised its attention to 'really fundamental thingsart, love, religion, science, work' ${ }^{18}$ Advertisements for the book seemed to agree with Masefield's protagonist that 'science is the art of the twentieth century' (138), insisting:

In 'Multitude and Solitude', Mr Masefield endeavours to treat the problem that presents itself to the artistic temperament in a generation whose inspiration is scientific rather than artistic. His first novel 'Captain Margaret' was romantic and of a past age; 'Multitude and Solitude' is actual and of the present day. ${ }^{19}$

In Multitude and Solitude, critics agreed, Masefield had 'left the romantic period in which he placed Captain Margaret and has given us a study of to-day'. ${ }^{20}$

In 1929, the novel was invoked by a journalist reporting on a speech given by South African politician Jan Hendrik Hofmeyr (1894-1948). Hofmeyr, speaking at the British Association meeting in Cape Town, made clear his feelings that Afrikaners could have their own distinct national identity whilst remaining under British imperial rule. He spoke of

\footnotetext{
16 “"The Bookman" Prize Competitions' The Bookman 36.216 (September 1909) 268-70 (p. 270).

17 'Multitude and Solitude' The Sketch, Wednesday 11 August 1909, p. 34.

18 'Multitude and Solitude by John Masefield' The North American Review 204.733 (1916) 941-42.

19 'Multitude and Solitude by John Masefield' Athenaeum 4261 (Saturday 26 June 1909) p. 769.

20 'Multitude and Solitude' Dundee Courier, Saturday 24 July 1909, p. 7.
} 
'one great land-Briton and Afrikander-a civilised native raised and treated with justice'. The reporter argued that

the South Africa of which he speaks is not that of "She" and "King Solomon's Mines" but of John Masefield's "Multitude and Solitude". Allan Quatermain saw his enemies as the native and the lion. Masefield sees more clearly. Man's enemy there is the small, the invisible, the tse-tse fly and the mosquito. ${ }^{21}$

By invoking a comparison between the romance of King Solomon's Mines and the realism of Multitude and Solitude, the reporter tacitly inscribes a watershed in colonial relations in which the threat posed by indigenous people and animals is replaced by the threat of indigenous parasites and their vectors. The comment reminds us that, for many, the British Empire was made visible and coherent by imperial fictions, which, in turn, influenced popular understandings of colonial politics.

At the turn of the century, another novelistic encounter that was invoked to contextualise British imperial politics was Henry Seton Merriman's With Edged Tools (1894). Merriman, a pseudonym for Newcastle-born author Hugh Stowell Scott (1862-1903), was a keen traveller and novelist. With Edged Tools was his fifth novel and it became an instant hit. He was widely praised for steeping the tale in 'African feeling and sentiment', with critics comparing him to Kipling, Conan Doyle, and Thackeray. ${ }^{22}$ One reviewer, wondering whether Merriman was bound for greatness, remarked 'Mr Merriman writes so well that one is disappointed that he does not write better, [he writes] as an English gentleman talks in mixed company' but is, they note, like Thackeray, 'too fond of the cynical aside'. They concede however that his men are 'real flesh and blood creations; his scenery-whether it be the Russian steppes in The Sowers or the tangled jungle of Africa in With Edged Tools - is vividly photographed upon the mind's eye of the reader' ${ }^{23}$ Indeed, Merriman was such a good storyteller that in 1898, one correspondent wrote to Adelaide's Express and Telegraph to ask whether it was fiction at all: 'Having just read a book called "With Edged Tools," by H. Seton Merriman, I should like to know

21 'South Africa' Northern Whig and Belfast Post, Tuesday 23 July 1929, p. 6.

22 'With Edged Tools' London Daily News, Wednesday 25 April 1894, p. 6.

23 'Mr Henry "Seton Merriman"' The Academy, 1335 (4 December 1897) p. 490. 
whether it was true that there was a very valuable drug found in Central Africa, called "Simiacine". ${ }^{24}$

The novel was serialised in Britain's Cornhill Magazine (July 1893June 1894), in Melbourne's The Age, and The Leader, and in Brisbane's Queenslander. It was novelised the same year by Elder Smith and Co., quickly reprinted as 'cheap', 'thin paper', and 'popular' editions, and published with Macmillan's Colonial Library. The News of the World dubbed the novel 'one of the best novels of the English spring season' and the Daily Telegraph remarked that it was 'a really fine and thoroughly original story' that 'cannot be praised too highly'. ${ }^{25}$ The Sheffield Daily Telegraph called it a 'deservedly popular novel', the Derby Daily Telegraph thought it a 'widely-read masterpiece', and the Lancashire Evening Post regarded it as Merriman's 'greatest work'. ${ }^{26}$ In 1909, the Shields Daily News proclaimed it was 'the most widely read novel in the world'. ${ }^{27}$ It was adapted for the stage in 1907 and toured throughout England and Scotland with great success. ${ }^{28}$ National newspaper The Era-famous as one of the most important theatrical journals in London-reported warmly on the adaptation, claiming that the book had been 'read by over two million people'. ${ }^{29}$ Meanwhile, the Staffordshire Sentinel reported that the play being in town had caused 'a run on copies of Newnes' sixpenny copyright edition being sold at the Hanley railway bookstall'. ${ }^{30}$ When it was adapted for the silver screen in 1920, early cinema journal The Bioscope noted it was a "world

${ }^{24}$ F. M. V. Hector, 'Dispatch Bag', The Express and Telegraph, Saturday 10 September 1898 , p. 2.

${ }^{25}$ Quoted in 'Foreign and British News' The Mount Barker Courier and Onkaparinga and Gumeracha Advertiser, Friday 14 December 1894, p. 3, and 'With Edged Tools', Truth, Thursday 17 May 1894, p. 44.

${ }^{26}$ 'With Edged Tools', Sheffield Daily Telegraph, Tuesday 29 September 1908, p. 11; 'With Edged Tools', Derby Daily Telegraph, Wednesday 23 February 1921, p. 5; 'With Edged Tools', Lancashire Evening Post, Thursday 25 February 1909, p. 1.

27 'With Edged Tools', Shields Daily News, Friday 10 September 1909, p. 3.

${ }^{28}$ The novel was also adapted into a play by a different company in Australia.

${ }^{29}$ The Era, Saturday 14 September 1907, p. 3. See also Merthyr Express, Saturday 10 October 1908, p. 7, who made similar claims, and the Northern Daily Telegraph, who stated it was the 'most popular book in the world, it having been read by over 2,000,000 people', Friday 11 February 1910, p. 1. It was also adapted for the stage in Australia, see: 'Grease Paint' The Mirror, Friday 18 Sep 1908, p. 16.

30 'With Edged Tools', Staffordshire Sentinel, Tuesday 16 February 1909, p. 4. 
famous novel', whilst the West Sussex County Times considered the story 'too well known to need any description'. ${ }^{31}$

This widespread popularity perhaps explains the use of the novel to contextualise global news about sleeping sickness. Whilst reporting on two cases of sleeping sickness that had been brought to London from the Congo in 1898, the Indian Medical Gazette and the Pall Mall Gazette both invoked With Edged Tools as a frame of reference. The former recommended the novel as providing a description of the disease as 'a deadly sleep from which [you] never w[a]ke', and the latter wrote:

The sleeping sickness, as Mr Merriman presents it, is a sudden and fatal torpor, against which men fight bitterly; and it disposes of his villain, a halfbreed negro, in the most terribly dramatic way. ${ }^{32}$

Meanwhile, a review for With Edged Tools in the London Standard immersed the novel within discussions of racial susceptibility to tropical illness, asserting:

The medical faculty knows very little about the "sleeping sickness" of Africa, regarding it as a sporadic affection peculiar to negroes; but Mr Merriman has discovered that it is a deadly and highly contagious epidemic, capable of sweeping off great companies of people at a blow, and as dangerous to white men as to black. ${ }^{33}$

In 1902, Australian newspaper the Norseman Times, reporting on the Ugandan epidemic of sleeping sickness, remarked that 70,000 natives had died of the disease in the preceding four years and 15,000 were at present suffering. ${ }^{34}$ They further commented, 'those who have read H. S. Merriman's fascinating novel "With Edged Tools" will remember a graphic description of the disease'. ${ }^{35}$ Another Australian newspaper,

31 'With Edged Tools' The Bioscope, Thursday 1 January 1920, p. 109; 'With Edged Tools', West Sussex County Times, Saturday 16 April 1921, p. 6.

${ }^{32}$ S.G. 'The Sleeping Sickness in a London Hospital' Pall Mall Gazette, Wednesday 12 April 1899, pp. 1-2.

33 'Five New Novels' London Standard, Tuesday 28 August 1894, p. 2.

${ }^{34}$ Maryinez Lyons contends that by 1905, the sleeping sickness epidemic in Uganda had killed nearly 300,000 Africans, though estimates vary considerably. Lyons, 'Public Health in Colonial Africa: The Belgian Congo' in The History of Public Health and the Modern State ed. by Dorothy Parker (Amsterdam: Rodopi, 1994) pp. 356-84 (p. 365).

35 'Sleeping Sickness' Norseman Times, Tuesday 30 December 1902, p. 2. 
reporting on Lieut-Col David Bruce's investigations into the causative agent of the disease ended their report with the remark: 'a fairly popular and accurate account of its effect will be found in H. S. Merriman's "With Edged Tools"'. ${ }^{36}$ Such unqualified endorsements in national newspapers and in the medical press are particularly problematic when we consider that they were invoked in the context of a colonial medical culture that depended largely on the repetition of anecdote. ${ }^{37}$ Both the repetition of the story of owa na ntolo in medical texts and Merriman's novelistic depiction of sleeping sickness contributed to the widespread characterisation of Africa as a place of pathological violence. Writing of the Bakongo (a blend of Bantu-speaking peoples who live along the Atlantic coast of Central Africa) explorer Herbert Ward insisted that anger 'is an emotion they feel very powerfully' and that it sometimes drives them to suicide (45).

With Edged Tools employs what Neil Hultgren calls the 'melodramatic mode', a mode that was 'one of the central fictions through which another fiction-that of the British Empire-might be understood'. Its power to make the British Empire 'appear unified and comprehensible' lay partly in its 'reimagin[ing of the Empire's] complexities via readily accessible binaries', such as race. ${ }^{38}$ Hultgren argues that these binaries entered into diverse negotiations with imperial propaganda and thus occupied a 'fraught ideological position in relation to violent imperialism' (2). We can read this fraught position in Merriman's novel where the melodramatic mode's 'obsession with moral turpitude and poetic justice' is writ large.

The novel follows British gentleman Jack Meredith as he embarks on an expedition to cultivate a secret African wonder-drug called Simiacine. Jack covets adventure and fortune so that he can marry his fiancée, Millicent Chyne, against his father's wishes. He has two business partners: British big game hunter, Guy Oscard, and West Indian trader Victor Durnovo, who we soon find out is the villain of the piece. The novel culminates in a fierce and drawn-out battle to protect the plateau where the Simiacine grows. During the siege, Guy and British domestic servant Joseph find out that Victor is a secret slave-owner, a crime so objectionable that Joseph exclaims: 'I wonder God lets yer stand there. I can only think that $\mathrm{He}$

36 'Cables. The Sleeping Sickness' Evening Courier, Wednesday 23 September 1903, p. 3.

${ }^{37}$ Warwick Anderson, 'Immunities of Empire: Race, Disease, and the New Tropical Medicine, 1900-1920' Bulletin of the History of Medicine 70.1 (Spring 1996) 94-118 (p. 99).

${ }^{38}$ Neil Hultgren, Melodramatic Imperial Writing from the Sepoy Rebellion to Cecil Rhodes (Athens: Ohio University Press, 2014) p. 3. 
doesn't want to dirty His hand by striking yer down!' (246). They wash their hands of the business and inform the slaves that they are free. When given the choice, however, the slaves elect to stay with Victor, a decision that strikes Patrick Brantlinger as Merriman 'impl[ing] that Africans are not suited to freedom'. ${ }^{39}$ Indeed, Merriman describes them at length as 'dumb and driven animals' (321). However, their apparent allegiance to the slave-owner is a calculated move in order to enact their revenge: the mutilation of Victor's face: '[they cut his] eyelids away, leaving the round balls staring, blood-streaked; cut away his lips, leaving the grinning teeth and red gums; shear[ed] off his ears' (282). Victor's 'terrible caricature of a grin' is so harrowing that even stoic Guy has to 'gulp down his nauseating horror' (377). In the novel, black Africans are thus presented as either exploited slaves or violent torturers.

Not content with this graphic punishment, Merriman provides further poetic justice in the form of sleeping sickness, a death sentence that is interpreted as Divine retribution for a man who had lived 'in dread' of the disease:

So, after all, Heaven stepped in [...] but there was a strange irony in the mode of death. It was strange that this man, who never could have closed his eyes again, should have been stricken down by the sleeping sickness. $(285)^{40}$

After all, 'it was one of Heaven's laws that Victor Durnovo had broken' (330). As he dies, his 'stained soul' leaves his body in the hands of 'the big strong Englishman [who shakes] the corpse, trying to awake it from that sleep which knows no earthly waking' (381). Whilst readers might have been struck by the violence of the punishment meted out by the slaves-'a yelling laughing horde of torturers' (378)-Merriman endows tropical illness with an equal capacity for horror. 'With the dread microbe of the sleeping sickness slowly creeping through his veins', Victor had fled the plateau and left 'a memento behind him surer than their torturing knives, keener than their sharpest steel—he had left the sleeping sickness behind

\footnotetext{
${ }^{39}$ Patrick Brantlinger, 'Victorians and Africans: The Genealogy of the Myth of the Dark Continent' Critical Inquiry 12.1 (1985) 166-203 (p. 181).

${ }^{40}$ This punishment and the 'grim legacy' that Durnovo leaves in his wake are made more poignant if we consider the historical intertwinement of sleeping sickness and the slave trade. See, for example, Dietmar Steverding, 'The History of African Trypanosomiasis' Parasites and Vectors 1.3 (2008) 1-8.
} 
him' (382). In this way, the colonial encounter is beset by the violence of exploitation, retribution, and deadly disease. Victor's death brings home to the reader the horror of owa na ntolo.

\section{RACE AND ILLNESS}

Merriman strategically restricts the melodramatic mode to his representations of illness and Africans, complementing a trend in colonial medical writing for employing sensationalist rhetorical tropes that 'embellished the way colonial-medical experiences were conveyed'. ${ }^{41}$ As Anna Crozier has argued, in colonial medical writing, 'whites were distinguished from blacks in their experience of ill health', following a 'rule of colonial difference' that often 'juxtaposed western ingenuity against racialised constructions of Africa and the African peoples as inherently pathological'. Such depictions were, she argues, 'a means by which colonial rule was conveyed as an acceptable venture at home', contributing to 'the legitimisation of whites in historically non-white places' (394). This collision between medicine and the racial politics of imperialism is particularly visible in discussions of sleeping sickness.

Sleeping sickness, or human African trypanosomiasis, is a parasitic disease caused by Trypanosoma brucei and spread via the bite of infected tsetse flies. Its symptoms include fever, headaches, itchiness, joint pains, fatigue, and swollen lymph nodes. As the disease progresses, neurological symptoms may develop such as tremors and seizures, and a disrupted sleep-wake cycle, as well as aggressive behaviours, apathy, and delirium. Without treatment, the condition invariably ends in coma, systemic organ failure, and death. Before the causative agent and insect vector were identified in the early twentieth century, little was known about the disease except that it was endemic to a narrow geographical range in Western and Central Africa, and was invariably fatal. Despite the British Medical Journal claiming in 1875 that cases of sleeping sickness had been reported in Europeans, the illness was consistently represented as one that only affected black Africans. ${ }^{42}$ British family periodical Bow bells announced to

\footnotetext{
${ }^{41}$ Crozier, 'Sensationalising Africa: British Medical Impressions of Sub-Saharan Africa, 1890-1939' The Journal of Imperial and Commonwealth History 35.3 (September 2007) 393-415 (p. 393).

${ }^{42}$ See: Albert A. Gore, 'The Sleeping Sickness of Western Africa' British Medical Journal $1.731(1875) 5-7$.
} 
its readers in 1895 that 'in Africa there is a disease that attacks the natives and that, although not uncommon, is yet involved in mystery'. Sleeping sickness, the writer insisted, is confined to black populations and only attacks 'young men and boys between the ages of twelve and twenty'. ${ }^{43}$ In 1898, the Sheffield Evening Telegraph also drew attention to the disease's perceived racial profiling, noting that the appellation 'negro lethargy' was a result of it being 'practically confined to negroes'. The article insisted that no 'authentic cases' had occurred in 'pure-bred white men' but conceded that the disease had been reported in 'moors and half-breeds' ${ }^{44}$

In 1899, the Pall Mall Gazette reported on the two Congolese cases of sleeping sickness that were currently under Patrick Manson's care at the Charing Cross Hospital. They again drew on the cultural currency of With Edged Tools and perpetuated the belief that it was a racially specific illness by exclaiming:

[W] hoever read Mr Seton Merriman's brilliant West African novel "With Edged Tools" will remember how he introduced into his plot this mysterious disease from which white men are exempt but which ravages the black populations, slowly irresistibly killing out whole villages. ${ }^{45}$

The patients-20-year-old Eli Mboko and 11-year-old Tendo Mkaloo, both from the same African village, Mbanza Manteka-had been brought to the hospital to receive treatment and to become the subjects of medical research. In describing the clinical cases, the correspondent emphasised the racial characteristics of the suffers:

[They are] negroes of the extremist negroid type, black as a new polished boot, their hair very short and woolly, like an animal's; the lower jaw very prominent, and the nose almost imperceptible above an enormously wide mouth, with lips that looked as if they had been rolled back. (2)

43 'Sleeping Sickness' Bow bells: A Magazine of General Literature and Art for Family Reading 32.407 (18 October 1895) p. 408.

44 'Sleeping Sickness' Sheffield Evening Telegraph, Saturday 3 December 1898, p. 3.

45 'The Sleeping Sickness in a London Hospital' Pall Mall Gazette, Wednesday 12 April 1899 , p. 1. The opening was also reframed for an article in the Greenock Telegraph and Clyde Shipping Gazette reporting on a Royal Society-funded commission to Uganda in 1902. See: 'Sleeping Sickness' Greenock Telegraph and Clyde Shipping Gazette, Wednesday 30 April 1902, p. 4. 
Such derogatory remarks were framed by a 'medical gaze' as the writer recounted his journey from hospital bedside to hospital bedside accompanied by celebrated tropical pathologist, Dr Patrick Manson. The writer concludes 'this little black creature $[\ldots]$ on the white bed was one of the strangest objects I ever looked at [...] here was this little piece of sunscorched humanity, drawn from his tropics, from among the sweltering rankness of jungle life, and laid down in the cold, clean whiteness of Europe'. ${ }^{46}$ Felix Driver and Luciana Martins argue that 'tropicality has frequently served as a foil to temperate nature, to all that is modest, civilized, cultivated' ${ }^{47}$ Whilst British understandings of the tropical world were by no means entirely coherent or consistent, characterisations like these helped to produce Europe as a space of temperance in nature and culture in contrast to tropical pathology and excess, to the 'sweltering rankness of jungle life'.

The juxtaposition between Tendo Mkaloo and the 'cold clean whiteness' that surrounds him is reiterated when the writer interprets his experience of illness as a product of his race, writing:

Negro children, it seems, do not cry out like European children $[\ldots]$ his hands lay on the counterpane, not closed like a European's would be, but slack and open, palms upward; and the inside of the palm pinkish like a monkey's. It was pitifully unhuman, and one felt that kind of unbearable sorrow that comes from the sight of a dumb beast in pain. (2)

Whilst here the correspondent attributes the perceived emotional apathy of Mkaloo to racial difference, Manson, in his chapter on sleeping sickness, includes it in the symptomology of the disease. He recounts the symptoms as occipital headache, fever, and diarrhoea, and then he notes a trajectory in which the patient 'becomes taciturn, morose and sad looking', bringing emotion within the purview of medical diagnosis. ${ }^{48} \mathrm{He}$ repeats the same symptomology in A System of Medicine edited by English

\footnotetext{
${ }^{46}$ S. G. 'The Sleeping Sickness in a London Hospital' Pall Mall Gazette Wednesday, 12 April 1899, pp. 1-2.

${ }^{47}$ Felix Driver and Luciana Martins, 'Views and Visions of the Tropical World' in Tropical Visions in an Age of Empire ed. by Felix Driver and Luciana Martins (Chicago: University of Chicago Press, 2005) pp. 3-19 (p. 11).

${ }^{48}$ Patrick Manson, 'Negro Lethargy, or the Sleeping Sickness of the Congo' Hygiene and Diseases of Warm Climates ed. by Andrew Davidson (Edinburgh \& London: Young J. Pentland, 1893) pp. 503-10 (p. 505).
} 
physician Thomas Clifford Allbutt in 1897, adding to the diagnostic criteria for sleeping sickness 'a sadness or apathy of expression, and a moroseness of disposition' ${ }^{49}$

In a clinical lecture about Eli Mboko and Tendo Mkaloo given in 1898, printed in the Journal of Tropical Medicine and the British Medical Journal in the same year, Manson again conflated the emotional experience of illness with its symptoms. Alongside enlarged lymphatic glands, fever, pruritus, constipated bowels, and Filaria perstans parasites in the blood, he notes that '[Mboko's] face has an expression of deep melancholy'. Meanwhile, he interprets Mkaloo 'laugh[ing] occasionally' as evidence of his clinical improvement and success of the treatment. Under a section on aetiology, he impresses his listeners with a picture of a typical patient's emotional trajectory as the disease progresses: 'indifference $[\ldots]$ a stolid rather mournful expression of countenance $[\ldots]$ he becomes morose and unsociable'. ${ }^{50}$

This seems like an odd diagnostic quirk on Manson's part; indeed, one imagines it would be difficult to distinguish the sadness of sleeping sickness from the moroseness of anyone suffering from a severe, long-term illness. Manson insists that 'the science of pathology embraces black men as well as white men; the principles of pathology are the same for all'; nevertheless, observations like those above veer from the medical to the anthropological, demonstrating a racialisation of emotions that persistently characterised sleeping sickness as an extension of what was perceived to be the innate laziness and apathy of black Africans. As parasitologist G. C. Low reported in his article on sleeping sickness, the disease had historically been linked with emotions associated with black African experience: 'the first observers believed that it might originate from emotional distress connected with negro slavery'. ${ }^{51}$

Manson's continued use of the outdated term negro lethargy, along with his insistence that the disease should be 'theoretically interesting' to white medical students, illustrates his implicit racial bias. Throughout the lecture he rejects the idea that sleeping sickness is 'an ethnic disease' and yet chooses to describe the symptom onset with reference to race: 'A

${ }^{49}$ Patrick Manson, 'Negro Lethargy, or Sleeping Sickness’, p. 482.

${ }^{50}$ Patrick Manson, 'A Clinical Lecture on the Sleeping Sickness, delivered at Charing Cross Hospital, October 1898' Journal of Tropical Medicine, December 1898, pp. 121-28 (p. 123).

${ }^{51}$ G. C. Low, 'Sleeping Sickness' p. 212. 
negro, otherwise apparently in good health, is unaccountably smitten with a gradually increasing mental and bodily lethargy'. ${ }^{52} \mathrm{He}$ even frames the lecture with the caveat that medical students should 'embrace in [their] studies all forms of disease no matter though some of these diseases happen to be confined to a limited geographical area, no matter though they affect only what we, in our pride, consider an inferior race' (121). British illustrated newspaper The Graphic similarly perpetuated the racial politics of the disease in their fortnightly 'Chronicle of Science'. Despite admitting that several cases of the disease had been diagnosed in Europeans, they only included images of black African sufferers and described the development of the disease as the onset of headache, fever, disinclination to work, and a change in 'facial aspect' that was specific to race: 'a previously happy and intelligent looking negro becomes instead dull, heavy, and apathetic' ${ }^{53}$

\section{EMOTIONAL Epidemiology}

In 1902, Ronald Ross contributed a chapter on tropical sanitation for British journalist and human rights campaigner E. D. Morel's Affairs of West Africa. He began with a comparison between West Africa and India, labelling the former a 'completely barbarous country'. ${ }^{54}$ Nevertheless, he rejected the common accusation that African natives were incorrigibly indolent', instead insisting that they were 'better material for civilisation than East Indians'. He continued: 'I do not think the backwardness of West Africa can be wholly or even largely [attributed] to defects [of] character', but to the 'unhealthiness of the region' ${ }^{55} \mathrm{He}$ thus drew attention to pathologies of space over race. Notwithstanding what appears to be an appreciation for the universal impact of tropical illness, he nevertheless singled out the indigenous population as part of an inimical environment that challenged colonial settlement, a problem to be solved by domestic hygiene and public sanitation. To this end, he even excused the 'alcoholism and debauchery' of Europeans in the colonies as the result of the 'enervating climate' and 'the ever-present dread of serious sickness, the

${ }^{52}$ Manson, 'A Clinical Lecture', p. 123.

53 'A Chronicle of Science: The Causation of Sleeping Sickness' The Graphic, Saturday 18 July 1908, p. 26.

${ }^{54}$ Ronald Ross, 'Sanitary Affairs in West Africa' in Affairs in West Africa by Edmund D. Morel (London: William Heinemann, 1902) pp. 153-69 (p. 154).

${ }^{55}$ Ross, 'Sanitary Affairs', p. 155. 
constant stings of insects, [and] the unsavoury surroundings of a squalid native population' (157). Ross demonstrates what Warwick Anderson refers to as the 'relentlessly dichotomising European imagination', in which Asian and African bodies were frequently represented as 'diseased, lazy, grotesque - as symbolic inversions of a European social body'—but also as productive subjects who might be reformed under strict medical and sanitary protocols. ${ }^{56}$ In colonial medicine, "typologies of race provided Europeans with compelling generalizations to account for an otherwise bewildering array of biological and cultural differences, allowing colonial emissaries to write homogeneity onto foreign populations and onto themselves'. Writers constructed homologies of race and environment that were contingent on a persistent belief in an 'intimate relationship between tropical vegetation, tropical bodies, and tropical mentality' (238).

With Edged Tools imaginatively expresses the inherent tensions between viewing Africa through the lenses of racial primitivism and environmental pathology by inscribing 'moral microbes' into the air that are partly responsible for unethical behaviour. They underwrite a metaphor of irritability that ties immorality, emotion, and illness together in a combination unique to its geography:

$[\mathrm{T}]$ here are moral microbes in the atmosphere of different countries, and we must not judge one land by the laws of another. There is the fatalism of India, the restlessness of New York, the fear of the Arctic, the irritability of Africa. (52)

The 'irritability' of Africa is a reference to the perceived degenerative effects of the tropical world, which Merriman's narrator insists 'makes honourable European gentlemen' descend into 'brutal passions' and 'commit crimes of which they blush to think in after days' (51). Merriman thus elaborates an amorphous relationship between feelings, behaviours, and moral principles underpinned by a language of contagion that both naturalises and medicalises brutality in African space.

In Civilizing Emotions, Margrit Pernau and Helge Jordheim argue that a semantic network of emotional experience became associated with the concept of civility during the Scottish Enlightenment such that emotions

\footnotetext{
${ }^{56}$ Warwick Anderson, 'The Third World Body' in Companion to Medicine in the Twentieth Century ed. by Roger Cooter and John Pickstone (London: Routledge, 2003) pp. 235-45 (p. 235).
} 
like violent passion were deemed 'primitive', whilst emotional self-control was promoted as evidence of the civilisation of a given society. In the following century, this would become a template for defining levels of civilisation, the most civilised societies 'characterised not only by their economic and political development, but also by their particular ways of feeling' ${ }^{57}$ Europeans came to define themselves in opposition to the peoples and societies they encountered overseas, priding themselves on being 'active, disciplined, progressive, rational, hardworking and foresightful, while African and Asian peoples were seen as passive, stagnant, sensuous, emotional, indolent, and improvident' ${ }^{58}$ The ability to emotionally selfregulate was seen as a prerequisite for self-government and the melded discourses of primitivism and emotional violence were often wielded to justify the continued need for colonial governance, against a backdrop of circulating ideas about evolutionary polygenism, the postulation of common descent, and debates about acclimatisation.

In Merriman's novel, these circulating ideas are distilled into an unstable narrative juxtaposition. The uncontrollable passions of the inhabitants of Central Africa are contrasted with the reserved emotions of London's elites. When British protagonist Jack Meredith breaks off his engagement to his fiancée he acts with decorum, 'quietly, self-composedly', which leaves the lady frustrated: 'Millicent Chyne felt a sudden plebian urge to scream. It was all so heartlessly well-bred' (309). Constant self-policing and social training mean that Jack, 'the beau-ideal of the society man' (13), 'never risk[s] the "gentleman" to [show] the man' (17-18) and Millicent does not give in to her 'plebian urge'. However, Africa-and its tropical maladies - threaten to upend the status quo. The air in Africa poses epidemiological and emotional danger to travellers who might inhale 'wild unreasoning passion' into their lungs along with-as many do-malaria, smallpox, and sleeping sickness.

Merriman's emotional epidemiology is emphasised via descriptions of the landscape; 'Loango is the reverse of cheerful' the narrator informs us. Jack similarly remarks that the place is 'not cheery' (89). Meanwhile, the roar of the surf fills the atmosphere with 'a never-ceasing melancholy'

\footnotetext{
${ }^{57}$ Margrit Pernau and Helge Jordheim, 'Introduction' in Civilizing Emotions: Concepts in Nineteenth Century Asia and Europe ed. by Margrit Pernau and Helge Jordheim (Oxford: Oxford University Press, 2015) pp. 1-24 (p. 4).

${ }^{58}$ Michael Adas, 'Scientific Standards and Colonial Education in British India and French Senegal' in Science, Medicine, and Cultural Imperialism ed. by Teresa A. Meade and Mark Walker (Basingstoke: Palgrave, 1991) p. 5.
} 
(89) — an indictment of its insalubrity that foreshadows the somatic downfall of the characters. By using an emotional register to signal the threat of physical ill-health, Merriman mobilises a formal technique for building tension. However, the 'irritability of Africa' is much more than a metaphoric invocation of atmospheric danger; it is also a form that expresses the psychological labour of inhabiting colonial space and deep anxiety about European acclimatisation. When Jack first decides to travel to Africa, it is with his career and his marriage in mind. He is to become a politician and so he must 'get a specialty' - 'I must know more about some country than any other man; and when I come back I must keep that country ever before the eyes of the intelligent British workman' (30). Africa is 'the coming country', embodying the 'brilliant conglomerate of possibilities' of which Jack Meredith himself is described (14). However, the reality is a far cry from the tropical conservatory at home, where a thousand tiny lights 'half hidden among languorous scented flowers' bathe it in an English glow, and where the music of the ballroom can still be heard (19). Rather it is, in Victor Durnovo's words, 'a bit suggestive of hell' (57)—a place where 'nature is oppressive in her grandeur' and where man is recast 'a puny, insignificant, helpless being in a world that is too large for him' (62).

The power of Africa lies in 'the great African silence that drives educated men mad, and fills the imagination of the poor heathen with wild tales of devils and spirits' (67). In John Masefield's Multitude and Solitude (1909), the African silence is similarly conceived in terms of atmospheric danger. As the title suggests, it too offers a formal mirroring of the tropi$\mathrm{cal} /$ temperate divide, with the first half of the novel taking place in the 'multitude' of London, and the second half in the 'solitude' of West Africa. After his companion Lionel slips into a sleeping-sickness-induced coma, Roger (himself in an earlier stage of the same illness) appraises his surroundings: 'the darkness of loneliness, the loneliness of silence, the immanent terror of places not yet won' (268). 'The terror of places not yet won' is not only a comment on the instability of British imperial power, but of the unstable boundaries between nature and culture, a terror of 'giving way and relapsing to the barbarism about him' (262). Like Merriman, Masefield conceives of this relapse as precipitated by tropical space. Following a rainstorm that turns the camp into a quagmire, Roger contemplates the mud, fearing that 
it had been worked, not only into his skin, but into his very nature. He had never before known what it is to be really dirty nor what continued dirt may mean to the character. (207)

The relationship conceptualised here between tropical nature and personal character reflects a belief articulated in colonial medical writing that time spent in tropical climes was both morally and physically degenerating. Edward Birch, professor of medicine in Calcutta, for example, wrote in 1893 of the adverse effects of warm climates on the constitution of Europeans. He agreed with fellow medical writers that after six or seven years of age, English children raised in India must be sent home to England or they 'will deteriorate physically and morally'. ${ }^{59}$ This deterioration is due to the physical weakening of a constitution under prolonged climatic stress and to the learning of 'much that is undesirable' from their surroundings. The child will have a 'tendency' to deceit, vanity, laziness, and ignorance unless removed to the 'more bracing and healthy (moral and physical) atmosphere of Europe' (7). As Harish Naraindas has observed, medical texts like Birch's offered a generalised and generalisable characterisation of the 'tropical native' as 'lazy, indolent, anaemic, asthenic, and degenerate', and 'naturalised [a] moral rhetoric on climate' that 'threatened the possibility of being cast in his likeness by a prolonged stay' in the tropics. ${ }^{60}$ Merriman and Masefield voice this same apprehension by erecting unstable boundaries between body and environment-a phenomenon articulated in With Edged Tools by the dual forms of microbes and miasma.

\section{Tropical Neurasthenia and 'White-Man Lethargy'}

With Edged Tools is haunted by anxiety about men who 'go physically to the colonies [and] morally to the dogs' (95-96) positioning the novel in dialogue with tropical neurasthenia-a malleable concept that was invoked to diagnose chronic, nonspecific forms of ill-health and to explain undesirable behaviours exhibited by colonial officials. As Anna Crozier argues, '[T]he diagnosis was useful in the colonial context as a means of

\footnotetext{
${ }^{59}$ Edward Birch, 'The Influence of Warm Climates on the Constitution' in Hygiene and Diseases of Warm Climates ed. by Andrew Davidson (Edinburgh \& London: Young J. Pentland, 1893) pp. 1-24 (p. 7).

${ }^{60}$ Harish Naraindas, 'Poisons, Putrescence, and the Weather: A Genealogy of the Advent of Tropical Medicine' Contributions to Indian Sociology 30.1 (1996) 1-35 (p. 16).
} 
categorizing and regulating the behaviours of Europeans abroad'. ${ }^{61}$ Encompassing a wide range of symptoms, including fatigue and exhaustion; headache and palpitations; anxiety and depression; visual and auditory disturbances; memory and concentration problems; indigestion and bowel problems; and greater susceptibility to illness, the label was often used as a shorthand for a variety of mental and physical breakdowns in health. The condition, particularly in colonial contexts, was seen to compromise 'manly fortitude and racial strength' and was largely conceptualised in relation to white masculinity, being predominantly a diagnosis of the Caucasian middle classes (528). There were close links between this and metropolitan forms of neurasthenia that dominated diagnoses in Britain and America from the 1860s into the 1930s.

Whilst classical understandings of neurasthenia were amorphous, the family of nervous disorders to which the label commonly referred were largely conceptualised in relation to the stressors of modern life namely overwork, urban living, disrupted sleep, poor diet, mental overload, emotional strain, and new technologies of communication and commerce. ${ }^{62}$ For some, it was associated with a depletion of 'nerve force', leaving the body exhausted and unable to perform. For others, it corresponded to an inherent weakness or loss of tensile strength in the nerves themselves. The versatile and semantically capacious vocabulary of nerves and nervousness was mobilised to conceptualise embodied forms of psychological distress, including sub-forms like 'nervous dyspepsia' - a condition arising from a local 'irritation' of the nerves that was then distributed sympathetically around the body causing widespread and seemingly unconnected physical

\footnotetext{
${ }^{61}$ Anna Crozier, 'What Was Tropical About Tropical Neurasthenia? The Utility of the Diagnosis in the Management of British East Africa' Journal of the History of Medicine and Allied Sciences 64.4 (October 2009) 518-48 (p. 519).

${ }^{62}$ For discussions of neurasthenia and nervousness more generally, especially as diseases of modern life, see: Melissa Dickson, Emilie Taylor-Brown, and Sally Shuttleworth eds. Progress and Pathology: Medicine and Culture in the Nineteenth Century (Manchester: Manchester University Press, 2020); Marijke Gijswijt-Hofstra and Roy Porter, eds. Cultures of Neurasthenia: From George Beard to the First World War (Amsterdam: Rodopi, 2001); Janet Oppenheim, 'Shattered Nerves': Doctors, Patients and Depression in Victorian England (Oxford: Oxford University Press, 1991). For discussions of institutional, political, and social pressures placed upon middle-class men in the wake of new forms of modernity throughout the nineteenth century, see: Emilie Taylor-Brown, Melissa Dickson, and Sally Shuttleworth, 'Structures of Confinement: Power and Problems of Male Identity' Journal of Victorian Culture 24.2 (April 2019) 137-45.
} 
and psychological symptoms. ${ }^{63}$ Merriman translates this nervous irritability into a metaphor for the emotional, moral, and somatic 'dis-ease' that is engendered by existing in the torrid zone.

Tropical neurasthenia was conceptualised as a disease of isolation that 'provided an expedient means of categorizing European neuroses at a safe critical distance from indigenous mental health problems'. ${ }^{64}$ European nervousness in the tropics was explained as the result of being exiled from family, friends, and the civilisation of home, of the exciting and depressing influences of climate, and of the 'excessive irritation' of dealing with Africans (534). In With Edged Tools, Merriman encodes the triple threat of tropical illness, neurasthenic breakdown, and sociocultural contamination into an undifferentiated atmospheric danger-an 'irritability' that performs a complex analogy between race, feeling, and illness. For West Indian antagonist Victor Durnovo, this irritability is an indictment of his moral shortcomings, which are couched in overtly racial terms. He is emotionally violent, cowardly, deceitful, rude, and flirts with the British heroine Jocelyn Gordon in a way that one reviewer found 'too repulsive' when it was adapted for the stage. ${ }^{65}$ Such behaviour is frequently presented through the lens of his mixed-race heritage, his 'dark face' with its 'brown marble' skin (56), his 'very dark eyes' (57) and his 'skinny yellow fist' (50). However, this same behaviour is also framed by the language of microbiology. Victor is half-starved and restless, on the verge of jaundice, his eyes 'bilious, fever-shot, unhealthy', and his face 'disease-stricken' (56). Thus, his behaviour is delineated in relation to tropical illness-his violence, deceit, and moral bankruptcy explicitly mapped onto symptoms such as biliousness and fever. It is with the generalised pathology of Africa that he is afflicted: 'the irritability of Africa was upon him-had hold of him-gripped him remorselessly' (51). 'Irritability' thus becomes a euphemistic term for tropical experience, a conflation of a kind of moral hysterics: 'men quarrel about trifles and descend into brutal passion' (52) with tropical disease: 'he was treating himself scientifically for the irritability to which he had given way' (53). Perhaps it is the 'impulse of expansiveness

${ }^{63}$ I have explored this at length elsewhere: Emilie Taylor-Brown, "Being "Hangry": Gastrointestinal Health and Emotional Well-Being in the Long Nineteenth Century' in Gut Feeling and Digestive Health in Nineteenth-Century Literature, History and Culture ed. by Manon Mathias and Alison Moore (London: Palgrave Macmillan, 2018) pp. 109-32.

${ }^{64}$ Crozier, 'What was Tropical about Tropical Neurasthenia?', p. 523.

${ }^{65}$ Owing to him being portrayed as 'half-caste'. 'With Edged Tools. The Seton Merriman Play at the Theatre Royal' Staffordshire Sentinel, Tuesday 16 February 1909, p. 4. 
which ever lurks in West Indian blood' that makes Victor so susceptible, the narrator reflects (63). Perhaps it is the 'treacherous climate' which undermines his health, and exacerbates his already weak nerves; he has 'been too long in Africa' (168).

The narrator offers 'Extenuating Circumstances' for Victor's behaviour in the form of his racial heritage, rendering biological the 'contact zones' of empire: 'given a mixed blood-evil black with evil white-and what can the result be but evil?' (392). In Imperial Eyes, Mary Louise Pratt conceptualises 'contact zones' as

spaces in which peoples geographically and historically separated come into contact with each other and establish ongoing relations, usually involving conditions of coercion, radical inequality, and intractable conflict. ${ }^{66}$

The 'intractable conflict' of Victor's racial heritage mirrors his interactions with the indigenous natures and cultures of West Africa, as well as with the 'dread microbes' moving through his veins (282). Merriman's depiction of the colonial encounter in racial, cultural, and microbiological terms refracts the broad geopolitical tensions that structure the Anglo-European imperial imagination. Representing the colonial encounter as chiefly an encounter of conflict, he insists that peace-political and emotional-cannot be achieved in Africa:

The Powers may draw up treatise and sign the same, but there will never be a peaceful division of the great wasted land so near to Southern Europe. There may be peace in Berlin, or Brussels, or London, but because the atmosphere of Africa is not the same as that of the great cities there will be no peace beneath the equator. From the West Coast of Africa to the East men will fight and quarrel and bicker so long as human nerves are human nerves. The irritability lurks in the shades of boundless forests $[\ldots]$ it hovers over the broad bosoms of the hundred slow rivers $[\ldots]$ it is everywhere. $(51-52)$

By projecting violent emotions and behaviours topographically, Merriman characterises Africa as a place that is environmentally and politically ungovernable.

\footnotetext{
${ }^{66}$ Mary Louise Pratt, Imperial Eyes: Travel Writing and Transculturation, 2nd edn (New York: Routledge, 2008) p. 8.
} 
Unlike Victor, British big game hunter, Guy Oscard appears to be largely unaffected by the 'anger of the tropical elements' (132) owing to his 'denser nerves':

Oscard did not understand it. His denser nerves were incapable of comprehending the state of irritation and unreasoning restlessness into which the climate and excitement had brought Durnovo. (195)

Moreover, neither he nor Jack Meredith suffer from the smallpox epidemic that kills 10 out of the 11 natives because they have been 'enthusiastically vaccinated' (172). Naturally hardy constitutions and artificial immunity mean that British characters can withstand Africa's degenerating atmosphere. They even produce their own salubrious microclimates that protect those around them: 'the atmosphere of Jack Meredith's presence was preferable to that diffused by Victor Durnovo. There was a feeling of personal safety and dignity in the very sound of his voice which set a weak and easily-led man upon his feet'. Guy too brings a 'change to the moral atmosphere', which other characters find 'comforting' (235). Meanwhile Jocelyn's 'Englishness' is 'like a tonic' when Jack is recovering from illness (303). Nevertheless, at the end of the novel, Jack admits that

he was afraid of Africa; the Irritability of Africa had laid its hand upon him almost as soon as he had set foot upon its shore. He was afraid of the climate. (453)

Whilst Jack's 'well-bred calmness of demeanour' (22) protects him from the 'wild unreasoning passion' that infects Victor, he cannot escape 'the singular feeling of total relaxation and limpness which is only to be felt in the rain-ridden districts of central Africa' (146-47). This atmospheric limpness maps onto the 'singular slothfulness' (225) and 'constant neverceasing fatigue' (262) that leaves Jack towards the end of the tale 'lying between sleep and death in his bedroom' (275).

By invoking not only the 'subtle, tainted air that poisons the white man's blood' and the 'treacherous climate', but also microbes, vaccination, disinfection, and the elastic vocabulary of nervousness and irritability, Merriman draws on the flexibility of multiple aetiological modes. This permits him to elaborate a complex relationship between space, race, and sensibility that makes room for conflicting anxieties about masculinity, nationhood, racial fitness, and colonial politics. It is perhaps this rhetorical 
flexibility that led reviewers to disagree about Merriman's portrayal of the tropics. One critic - insisting that predictability was the 'grammar' of romance-lamented how tropical adventure was always full of illness, savagery, and failed business schemes:

when [the] twin heroes go to Africa in quest of a plant of the most grave and potent medicative virtues, they are as likely to return rich as the ordinary traveller is to return shrivelled and worn by agues and fevers; it is a 'dead cert' that they will have to fight savages. ${ }^{67}$

Another critic, however, read With Edged Tools as a triumph of British fortitude and imperial prowess. Comparing Merriman to Rudyard Kipling, they insisted that Merriman's novels were 'intensely patriotic', and that

to those who will read between the lines, he shows us that in his opinion the well-bred young Englishman can go anywhere and do anything. His heroes are just as much at home in Buluwayo or Bond street. ${ }^{68}$

This critic seems to be wilfully reading between the lines indeed. After all, Merriman himself writes that 'it would appear that [Jack Meredith] was not so much at home in the tangle of African forest as in the crooked paths of London society' (109). Indeed, the most pressing take away from this tale of adventure might well be how unsuited Englishmen are to African travel, Jack's 'thorough breakdown in health' (262) appearing to confirm Joseph's assertion that 'this country's not built for honest white menleast of all for born and bred gentlemen' (319).

Merriman's fraught narrative of disease susceptibility in West Africa bespeaks tensions in representation that also loomed large in medicine as writers tried to reconcile observation with ideology. The violence of sleeping sickness-embodied in Merriman's irritability metaphor and in the circulation of the cursed call to arms of owa na ntolo-enacts a racial politics that sought to delimit the experiences of black and white individuals in tropical space. This dynamic is apparent in the writing of British parasitologist John William Scott Macfie (1879-1948), who trained under Ross for a Diploma from the Liverpool School of Tropical Medicine in 1910. Between 1910 and 1922, he went on eight tours as a medical officer in

${ }^{67}$ 'With Edged Tools' The National Observer 12.296 (21 July 1894) 256-57 (p. 256).

68 'Mr. Henry Seton Merriman' The Academy 1335 (4 Dec 1897) p. 490. 
West Africa to study malaria, yellow fever, and sleeping sickness. Among his archives is a manuscript which begins:

Early voyages to West Africa described a terrible disease of the natives which transformed men previously bright, intelligent, and hard-working into dull, apathetic creatures careless in their work and dirty in their habits.

This disease, he informs us, is sleeping sickness, or as it was originally known 'negro lethargy'. ${ }^{69}$

For Macfie, sleeping sickness transforms useful workers into 'dirty' 'creatures' literalising an implied connection between primitivism and pathology. He then uses this concept to elaborate a new kind of aetiology, which he dubs 'white-man lethargy'. This condition only affects Europeans and, disproportionately, newcomers to the West Coast. 'It is not as fatal to life as is sleeping sickness', he asserts, but 'it is more fatal to hopes and ambitions and reputations'. The disease trajectory that Macfie goes on to relate dramatises a common medico-social anxiety: the racial and cultural degeneration of the European. The disease is insidious, beginning, as does sleeping sickness, with lethargy: 'the intelligent individual becomes dull, the bright apathetic, the energetic indolent, and the careful careless'. Then comes a change of character marked by emotional violence- irritability and outbursts of anger out of all proportion'-followed by 'obsession almost amounting to delusions of persecution'. The patient starts to display strange behaviour: 'some dress elaborately for dinner even under the most unsuitable circumstances when on a trek or in the "bush"'. Next, they begin to lose the vocabulary of civilised conversation, those who write 'find composition difficult or impossible', 'almost all fall into the habit of careless expression', and when visiting friends in Europe find themselves 'surprised at the sense of unfamiliarity they experience on hearing words which once they employed daily and are amazed at the shrinkage of their own vocabulary'. His depiction is less one of ill-health than of an inability to play the part of the European effectively.

The prognosis from here is not promising. Many cases develop into a neurasthenia that culminates in insanity or suicide: 'the final act of revolt against the tendency to lethargy'. Others reach a 'quiescent stage' as an 'efficient but damaged instrument', performing their duties 'successfully

\footnotetext{
${ }^{69}$ London. LSHTM. GB 0809 Macfie/03/05/03. Manuscript notes on Sleeping Sickness and 'White-Man Lethargy'.
} 
but mechanically', unable to learn new skills or assimilate new ideas. The patient is perpetually irritable and must carefully manage his energy, 'fundamentally he is slack - mentally, morally, and physically'. Such a declaration is continuous with popular conceptions of indigenous populations (who were often blamed for having 'backwards' social and sanitary predilections) and also with a history of presenting tropical climes as degenerating to white colonists. As Manson wrote in his seminal textbook in 1898, the European adjusting to the 'altered meteorological circumstances' of the tropics may undergo physiological 'irregularities' which include 'a tendency to degenerative changes' ${ }^{70}$

Using sleeping sickness as a model, Macfie delineates a new kind of illness that offers a scientific explanation for the laziness and irritability of white colonists. In extreme cases, he insists, a complete degeneration of the patient takes place 'end[ing] in a state of utter incompetence, living a slovenly life in a dirty and disordered house, speaking little but pidgin English and apart from his work associating almost exclusively with natives'. His aetiology makes medically palpable the imagined de-civilising influence of primitive and insanitary environments, suggesting that like Roger in Multitude and Solitude, the dirt of Africa might be worked not only into the colonist's skin but permanently into their very nature. The patient's 'pidgin English' and alarming social integration with indigenous Africans evokes the fear of 'going native'-popularly embodied by now archetypal figures like Kurtz from Joseph Conrad's Heart of Darkness (1899)—and demonstrates how medical forms were mobilised to draw racial boundaries. ${ }^{71}$

When drawing these boundaries medical writers often made use of a sensational register that dovetailed with a longer literary tradition of travel writing and missionary biography. This is particularly the case in discussions of British-African territories post 1880. As Crozier argues, 'one means of articulating the huge gulf between blacks and whites [was] by re-casting ubiquitous diseases as primarily African ones'.$^{72}$ In addition to

\footnotetext{
${ }^{70}$ Manson, Tropical Diseases, p. xii.

${ }^{71}$ Charlotte Rogers has explored the complex relationships between language and madness in literary texts like Heart of Darkness. She argues that depictions of Africa as a place of silence or African languages as incomprehensible grunts or mad ravings were narrative strategies that attempted to maintain boundaries between sane, white, civilisation and insane, black, primitivism. Kurtz's own inability to voice himself comprehensibly demonstrates the mutability of these categories. Rogers, 'Medical Discourse and Modernist Prose' in Jungle Fever: Exploring Madness and Medicine in Twentieth-Century Tropical Narratives (Nashville: Vanderbilt University Press, 2012) pp. 29-62.

${ }^{72}$ Crozier, 'Sensationalising Africa', p. 407.
} 
the persistent and sensational racialisation of sleeping sickness (as explored in this chapter), discussions of diseases like malaria were reformulated in ways that pathologised indigenous Indian and African bodies and behaviours. In his treatise on malarial fever, Ross advises the use of mosquito nets, quinine, and racial segregation as the chief prophylaxis against tropical diseases, including malaria, yellow fever, and elephantiasis: 'avoid as much as possible sleeping in the houses of natives [...] sleep in a native house often means death [...] one of the chief reasons why Europeans are more healthy in India than in some other tropical countries, is, I think, because in India they generally live in separate quarters' ${ }^{73} \mathrm{He}$ singles out the native population, particularly native children, as reservoirs for the parasites, arguing that 'more than half the native children are sometimes found to be infected by it'. Under the title 'domestic precautions' he lists the following:

1. Removal or protection of all stagnant water in the vicinity

2. Protection of the windows with wire gauze

3. Segregation

These protocols, he maintains, "should be adopted in private houses, factories, plantations, hospitals, barracks, etc" and advises that Europeans should 'double [their] precautions' if forced to sleep in or near a native village (36-37).

At best these passages illustrate how-despite its global rhetoric-tropical medicine primarily sought to benefit colonists, and at worst, how it was used to perpetuate political ideologies by providing a medical rationale for racial segregation. ${ }^{74}$ As Warwick Anderson has noted, 'framing disease, framing "environment", and framing "race" [were part of] the same manoeuvre-with political and social consequences perhaps as

\footnotetext{
${ }^{73}$ Ronald Ross, Malarial Fever, Its Cause, Prevention, and Treatment; Containing Full Details for the Use of Travellers, Sportsmen, Soldiers, and Residents in Malarious Places 9 th edn (London and Bombay: Longmans, Green, and Co., 1902) pp. 41-45 [emphasis in original].

${ }^{74}$ Crozier identifies similar advice in a range of medical writing, including Dr Ryan's 1914 health manual which begins with the statement that 'this is par excellence the preventative measure' and then goes on to stress 'the vital importance of avoiding the building of European quarters in close proximity with those of the natives'. Anna Crozier, 'Sensationalising Africa', p. 407.
} 
profound as any military deployment' ${ }^{75}$ These concepts: disease, environment, race, and military deployment come together in Ross's 1902 book Mosquito Brigades in which he seeks to 'commence a war against our winged enemies' using a regimented system of drainage, clearance, and mosquito extermination. Whilst suggesting that such brigades might be staffed by indigenous workers, they must be led and directed by European administration. He warns against starting mosquito brigades in native towns and villages where they will 'scarcely be possible' because 'there will be no one to direct them' and clarifies that they should be carried out in 'isolated houses [...] where white men live', in 'plantations, mines, and farms where white men live and labour is abundant', and in 'all settlements where white men live in any numbers'. It is advisable to start a 'campaign' he concludes 'wherever the game is worth the candle' (45). In the next chapter, I explore these intersections more fully by investigating the collision of military and medical forms in professional and popular depictions of the parasite-vector-host relationship.

${ }^{75}$ Warwick Anderson, 'Disease, Race, and Empire' Bulletin of the History of Medicine 70.1 (Spring 1996) 62-67 (p. 63).

Open Access This chapter is licensed under the terms of the Creative Commons Attribution 4.0 International License (http://creativecommons.org/licenses/ by $/ 4.0 /$ ), which permits use, sharing, adaptation, distribution and reproduction in any medium or format, as long as you give appropriate credit to the original author(s) and the source, provide a link to the Creative Commons licence and indicate if changes were made.

The images or other third party material in this chapter are included in the chapter's Creative Commons licence, unless indicated otherwise in a credit line to the material. If material is not included in the chapter's Creative Commons licence and your intended use is not permitted by statutory regulation or exceeds the permitted use, you will need to obtain permission directly from the copyright holder.

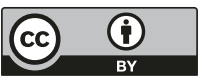

